\title{
Article
}

\section{More than a grand day out? Learning on school trips to science festivals from the perspectives of teachers, pupils and organisers}

\author{
Canovan, Cherry
}

Available at http://clok.uclan.ac.uk/30144/

Canovan, Cherry ORCID: 0000-0002-9751-5646 (2020) More than a grand day out? Learning on school trips to science festivals from the perspectives of teachers, pupils and organisers. International Journal of Science Education, 10 (1). pp. 1-16. ISSN 0950-0693

It is advisable to refer to the publisher's version if you intend to cite from the work. http://dx.doi.org/10.1080/21548455.2019.1680904

For more information about UCLan's research in this area go to http://www.uclan.ac.uk/researchgroups/ and search for <name of research Group>.

For information about Research generally at UCLan please go to http://www.uclan.ac.uk/research/

All outputs in CLoK are protected by Intellectual Property Rights law, including Copyright law. Copyright, IPR and Moral Rights for the works on this site are retained by the individual authors and/or other copyright owners. Terms and conditions for use of this material are defined in the policies page. 


\section{More than a grand day out? Learning on school trips to science \\ festivals from the perspectives of teachers, pupils and organisers}

Cherry Canovan ${ }^{\mathrm{a} *}$

${ }^{a}$ Communications and Engagement, University of Central Lancashire, Preston, UK

CB106 Chandler Building, University of Central Lancashire, Preston PR1 2HE,

ccanovan@uclan.ac.uk

Twitter: @DrCherryCanovan

ORCiD: 0000-0002-9751-5646

*corresponding author

Cherry Canovan is a research associate at the University of Central Lancashire. She obtained her PhD in Mathematical Physics from Lancaster University and previously worked as an education journalist. Her research interests include the impacts of science festivals, as well as widening participation in STEM and higher education more generally.

Word count: c. 9,500 


\title{
More than a grand day out? Learning on school trips to science festivals from the perspectives of teachers, pupils and organisers
}

\begin{abstract}
Science festivals are a rapidly-growing phenomenon worldwide, and many such events host trips by school parties. However what type of learning takes place on these visits, and how effective it is, has not as yet been a focus of $\underline{\text { is an area that }}$ merits more academic study. This paper investigates these questions from the perspective of three groups - teachers, pupils and festival organisers - and asks how well the attitudes and priorities of these categories are aligned. We find that teachers and organisers share the primary aim of affective learning (excitement, inspiration) and that this is experienced by almost all pupils. A secondary aim of cognitive (factual) learning is reported by just under half of pupils. However a third aim of careers learning which was expressed by festival organisers and some teachers was not reported by pupil participants. In addition, we found that the groups could work more effectively together to promote educational aims by measures such as reducing the novelty of the event situation and making educational agendas for the visit clearer. Finally, to address the areas of misalignment pinpointed in this study, we give a series of recommendations to optimise learning at such events.
\end{abstract}

Keywords: science festivals; public engagement; public understanding of science; out of school learning

\section{Introduction}

In recent years there has been a rapid growth in the science festival sector, both in the UK and internationally (Bultitude, McDonald, \& Custead, 2011). As well as welcoming the general public, many festivals have specific provision for school parties to visit.

However the learning that occurs on such visits has not as yet been a focus ofis an area that merits greater academic study.

In this paper we investigate learning on school trips to science festivals from three perspectives - that of the teacher, the pupil, and the organiser - and consider how well the attitudes and priorities of these groups are aligned, an approach previously 
adopted by Davidson et al (Davidson, Passmore, \& Anderson, 2009), and Illingworth et al (Illingworth, Lewis, \& Percival, 2015).

We ask what kind of learning science festivals are seeking to promote through school trips - whether they are seeking to transmit facts, build on in-school curriculum learning, or inform pupils about science more widely. We also consider the question of what type of learning teachers and pupils hope and/or expect to occur, and how well the festival offer aligns with these aims.

In order to address these questions, we interviewed the organisers of five UK science festivals that include school visits as part of their offer. We also carried out an in-depth study over two years at one of these science festivals, talking to both teachers and pupils about their learning experience.

\section{Science festivals}

Science festivals are a relatively modern phenomenon; the first such event was held in Edinburgh in $1989^{1}$. However their spread has been rapid; the UK Science Festivals Network now has more than 40 members, while the Science Festival Alliance has around 50 members in North America. In addition, many science festivals are held in continental Europe, Oceania, Asia and some in Africa.

The concept of a science festival is a heterogeneous one; Wiehe gives a flavour of the diversity apparent in the sector:

...the scale and ambition of festivals vary widely: annual budgets for the most and
least expensive are separated by a factor of 1,000, and geographic ambitions range
from reaching a single neighborhood, to covering entire states, to the even more
grandiose. Even the structures that science festivals employ differ greatly: some are 
multi-venue, multi-modal extravaganzas spread over a week or two; others concentrate their efforts on transforming a single venue into a science fairground for a weekend; still others find it best to eschew free-standing events and insert science activity into existing non-science gatherings... (Wiehe, 2014)

Perhaps because of their rapid growth, or maybe because of their diverse nature, science festivals have been a somewhat understudied phenomenon, although the literature is now developing. Given the complexity of the spectrum of events that constitute a science festival, it is perhaps understandable that researchers have chosen to focus on the various aspects in a modular fashion. Subjects such as motivations for attending (Jensen \& Buckley, 2014), preferences for engagement and learning formats (Fogg-Rogers, Bay, Burgess, \& Purdy, 2015), and impacts on parental attitudes to science (Canovan, 2019)(XXXX (REDACTED), 2019) have been addressed in recent years.

However school visits to science festivals is an aspect that has received relatively little attention, and the literature that does touch on the subject (Janiuk, 2013; Partridge, 2003) tends to be descriptive in character. One valuable addition to the field is provided by (Illingworth, Lewis, \& Percival, (2018), who studied the efficacy of a large schools science event in increasing knowledge of science careers among pupils age 11-14. Our study aims to build on this work by address this deficit by looking at science careers learning at festivals among primary-age pupils; we also -considering the type of learning that science festivals can and/or should provide to school parties, and how to position the experiences within the broader literature on learning in out-ofschool settings. It does so by drawing on research conducted with three key groups teachers, pupils, and festival organisers. 


\section{Learning on school trips}

In contrast to research on science festivals, the literature on learning on school trips is well-developed. Subjects such as teacher motivations (Kisiel, 2005), the behaviour of students in school groups (Griffin, 2004), gendered experiences of school visits to

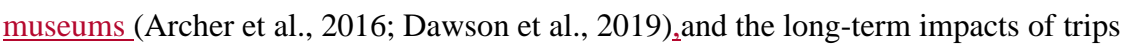
(Falk \& Dierking, 1997) have all been addressed, with recommendations to enhance learning made by a number of contributors.

\section{Types of learning}

Research suggests that school trips can be useful in terms of both cognitive learning, centred around knowledge and intellectual skills, and affective learning, centred around values, enthusiasms and attitudes (L. W. Anderson et al., 2001; DeWitt \& Storksdieck, 2008).

In terms of cognitive learning, Whitesell (Whitesell, 2016) found that attending an informal science education institution ${ }^{2}$ (ISEI) had a small positive effect on students' science performance. Meanwhile Anderson et al (D. Anderson, Lucas, Ginns, \& Dierking, 2000) conducted in-depth case studies with a group of 12 young people around a visit to a science museum and found that 'In all 12 [cases]... students experienced numerous small and subtle changes in their knowledge and understanding of electricity and magnetism.' Elsewhere, Dieser and Bogner (Dieser \& Bogner, 2015) found that an outdoor nature experience "produced a significant knowledge increase immediately after the intervention, which also persisted over a period of six weeks."

\footnotetext{
${ }^{2}$ For example science museums, science centres, zoos and botanical gardens.
} 
Meanwhile other researchers found affective learning impacts of school trips. Finson and Enochs (Finson \& Enochs, 1987) found significant differences in attitudes to science, technology and society between school pupils who had visited a science/technology museum and those who had not. Meanwhile Knapp (Knapp, 2000), who surveyed elementary school pupils one month and 18 months after a science field trip, found participants 'wanting to learn more about the subject matter and [with] an interest in returning to the field trip site'. A recent review of the literature on learning and engagement through visits to natural history museums by Mujtaba et al (Mujtaba, Lawrence, Oliver, \& Reiss, 2018) found that the settings "can provide students with new knowledge and perspectives in well-designed exhibits, with impacts that can last years," although the authors caution that there is little in the literature which studies the $\underline{\text { long-term impact of such visits on students' learning. }}$

There are some indications that affective learning may be a more effective outcome of school trips than cognitive gains. Belin (Belin, 2018), who conducted a controlled study of student visits to an ISEI, found that while overall students who attended had a more positive view of science than those that did not, only certain groups (boys, minority groups and first-time visitors) performed better in a cognitive assessment.

\section{Encouraging learning on school trips}

The factors that stimulate learning on school trips is a subject that has been widely covered in the literature, for example by DeWitt and Storksdieck (DeWitt \& Storksdieck, 2008), who give a series of suggestions as to how informal learning

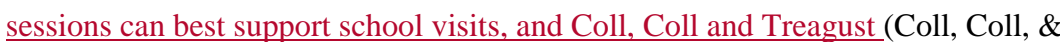
Treagust, 20158), who propose a framework for school trips to enhance learning outcomes (the Learner Integrated Field Trip Inventory, or LIFTI). 
How effectively learning occurs is affected by a number of considerations, many of them structural, for example whether there are multiple learning opportunities, how well the content is embedded in the curriculum, and whether there are both opportunities for free exploration and some structure to the trip. We consider how the operational structures of science festivals impact learning in our report- Learning on school trips to science festivals (Canovan, Granger, \& Luck, 2019)YYYY (REDACTED) (YYYY, 2019), and thus do not cover these here.

However there are some aspects of promotion of learning arising from the literature which are relevant to the current study, in that they are open to interpretation by the different stakeholder groups. These include:

- Are steps taken to reduce the 'novelty effect' for pupils that can negatively impact on learning?

- Are pupils aware of their teachers' expectations/agendas for their visit?

- Can attending the festival improve teachers' understanding of pupils' science motivations?

\section{The pupil's perspective}

While the literature on school trips is generally wide-ranging in scope, there is one area which has been cited as needing further investigation: students' own perspectives on non-formal learning experiences. Eshach (Eshach, 2007) states:

Usually, researchers are not interested in questions such as what the child thinks he will gain from his or her science field trip, or whether they think the field trip is important. Researchers are usually interested in and focus on children's attitudes and attitude changes towards science as a result of the fieldtrip... 
Our study has been explicitly designed in order to gather pupils' views about the purpose and effectiveness of school trips to science festivals.

\section{Research questions}

The above discussion leads us to pose two research questions:

(1) What learning occurs on school trips to science festivals, and does this learning align with the aims of organisers, teachers and pupils?

(2) How effectively do the three stakeholder groups work together to optimise the learning experience on these trips?

\section{Methods}

In order to investigate these questions, we instigated a multi-faceted study of school visits to science festivals. Our study involved five English science festivals of varying sizes and structures, all of whom provide dedicated sessions for school parties on-site at their events. In order to enable the festival organisers to speak freely about learning, we anonymise these festivals using the names LabFest, WhizzFest, WowFest, StarFest and ExperiFest.

The initial phase of the study was conducted before, during and after the 2017 WowFest. Pre-event surveys were conducted, either online or by telephone, with 20 teachers, and 13 of these also completed post-event surveys, with the remaining seven too constrained by time to participate in the second phase. In addition, structured interviews were conducted with 27 teachers while they were accompanying school trips during the festival itself.

Following this, a study involving pupils attending the 2018 WowFest was conducted. 124 pupils from seven schools completed pre-festival on-line surveys and 64 
pupils from six schools completed post-event surveys. Of these, 61 pupils completed both pre- and post-surveys. At school level, teachers organised the logistics of survey completion; one school did not find the time to complete the post survey, while others were not able to organise for all pre-survey participants to complete the second part, which explains the disparity in numbers between the two stages. Focus groups were also held before and after the event with pupils at three of the schools.

In addition, teachers were once again surveyed before and after the event, with 39 completing the pre-event survey and 29 the post-event survey; 11 of these completed both pre- and post-surveys. The links to both online surveys were sent out to all teachers attending the festival so that they could decide for themselves whether to participate in one or both surveys.

In order to explore how the experiences of teachers and pupils at WowFest might reflect those of school visits in the sector more widely, interviews were carried out with the festival organisers of LabFest, WhizzFest, StarFest and ExperiFest. Finally, a focus group was held with the WowFest organizational team to explore in depth their views on the role of learning at a science festival.

It should be noted that the schools participating in the pupil surveys do not fully represent the breadth of English primary schools. Schools were approached in two different ways: those where teachers had spoken to researchers in the first year of the study and had given permission to be contacted again, plus a second group who had a pre-existing relationship with the festival organisers through receiving other widening participation interventions. The latter group were more responsive, meaning that 
schools with high levels of pupil premium ${ }^{3}$ (PP) are strongly represented in the sample. In fact four out of our seven schools were in the top third of schools nationally by levels of PP, with two in the middle third and one in the bottom third. While the median primary in England in $2017 / 18$ had a PP of $18 \%{ }^{4}$, our median participating school had a PP level of $36 \%$ and our median pupil participant attended a school with a PP level of $52 \%$. It is important to note, therefore, that results obtained from a cohort drawn from $\underline{\text { schools in less-deprived areas might have yielded different results in some respects. }}$ However the views of young people and teachers from our response areas are valuable both in their individual standing and because these cohorts tend to be of particular interest to policymakers and those who seek to address societal imbalances in science and education more generally. In fact, as some festivals have a widening participation element among their aims and objectives, it may be of particular interest to explore the views of a cohort weighted in this way.However we do not feel that this imbalance detracts from the views of individual pupils or teachers; in fact, as some festivals have a widening participation element among their aims and objectives, it may be of particular interest to explore the views of a cohort weighted in this way.

\footnotetext{
${ }^{3}$ Pupil premium is additional funding for state schools in England which is designed to improve the performance of disadvantaged pupils of all abilities, and to close the gap between them and their peers.

${ }^{4}$ www.gov.uk/government/publications/pupil-premium-conditions-of-grant-2017-to-2018
} 
Results

\section{What learning occurs on school trips to science festivals, and does this learning align with the aims of organisers, teachers and pupils?}

a. Affective learning - making science exciting and changing attitudes

i. Expectations. Festival organisers were clear that their primary objective in staging their events was to change attitudes to science. Whilst there were slight differences in emphasis - WhizzFest and LabFest put a strong emphasis on informing participants about the importance and breadth of science, while WowFest and StarFest had the primary aim of exciting and inspiring visitors with the wonder of science - the overarching aims were in the affective domain.

One respondent, the ExperiFest organizer, was strongly of the opinion that fun should be not only the primary aim of the festival but the only aim. They said:

[The aim of the festival is] to enthuse children with the joy of science. I do not see our role as education... My aim is entertainment.

Further discussion revealed that the organiser expected a level of attitudinal change to take place:

[We] show kids interesting cool things, so they go back and the teacher can teach and educate having had children enthused with science...

In general, this emphasis on attitudes to science and providing a new and exciting experience chimed with teachers' expectations. Teachers interviewed either before their visit to WowFest or on the day overwhelmingly said that their primary aim in attending was to generate interest, engagement and motivation with regard to science. Typical comments include: 
[The festival will] spark their interest in science in ways they've not experienced before.

Inspiring young children and showing them the importance of science in the current and future world.

And what of the child's perspective? When asked before the trip why they thought the school was taking them to the festival, pupils very clearly felt the aim to be educational, with the most common single response being 'to learn more about science' or variants, given by $45 \%$ of respondents. When we add in respondents who mentioned learning more generally (12\%) and those who mentioned both learning and fun (7\%), we find that $64 \%(78 / 121)$ felt that their school was motivated by learning to take them to the festival.

There was some vagueness in the concept of what 'learning about science' entailed, with some suggesting factual (cognitive) learning - 'To find out new science things' - and other suggesting a more attitudinal (affective) approach, eg 'To help us understand about science'. However in our focus groups, an affective view in line with the priorities of teachers and organisers emerged. At Town Hill Primary, for example, the following exchange occurred:

Facilitator: Why does your school want to take you to the festival? [...] Miranda? Miranda ${ }^{5}$ : If you don't like science, you'll probably change your mind about it, so, when you're going to the festival.

Cherry: It's going to make the work more fun, because [for] some people like me sometimes all science is really boring. But, like different science, it makes it more... [interesting].

ii. Outcomes. Inspiring and enthusing pupils was named by both teachers and

\footnotetext{
${ }^{5}$ Pupil participants were anonymised using names of their own choosing.
} 
festival organisers as the primary purpose of the events, and the results from our WowFest pupil cohort certainly suggested a positive affective impact from attending. An overwhelming 95\% (60/63) of respondents agreed that the science at the festival was interesting, an important first step for attitudinal change (Kirkpatrick, 1994/2010). When we asked the pupils whether their experience of attending the festival had been what they were expecting, many suggested that it had exceeded expectations; typical comments included:

I loved it. I didn't know what to expect but when I got there [it was] the best day in school.

I thought it was going to be boring or not that cool or fun but it was actually great.

The level of interest and enjoyment was reinforced by the difference in answers to the questions 'What was the best bit of your visit?' and 'What was the worst bit of your visit?' The first question was answered by almost everyone, with only 1/64 not responding, and the others all either specified an aspect of their festival experience as their favourite part or said they liked all of it. By contrast, only 56/64 answered the second question; of those that answered, 24 said that nothing had been the worst bit, while a further 12 only named operational aspects such as too much walking or waiting for a bus. Only 16/64 cited a scientific experience as being the 'worst' aspect of the festival.

Examples of the most interesting aspects of the science at the festival reported by pupils included both affective and cognitive elements-:

Finding out about the length of sharks.

Experiments that I did not know existed and I got to try them.

The most interesting thing was getting to see it with my own eyes rather than getting told it . 


\section{b. Cognitive learning}

i. Expectations. The festival organisers were unanimous that the primary aim of school visits to their events is not to teach the curriculum; although festivals varied as to the emphasis they put on cognitive learning, none saw this as their primary aim. For example, WowFest organiser Abbie ${ }^{\underline{6}}$ said their festival aimed to '...complement learning that's happening, help engage [children], to inspire them to keep going with lessons.'

However when we probed festivals' motivations in greater depth, a role for cognitive learning also emerged as a necessary underpinning for the stated aims of affective learning. WowFest organiser Lucy ${ }^{7}$ said:

We do want quality content and try to steer people towards things that are educational, but that's not because we want people to leave saying 'I've learned X, $\mathrm{Y}$ and Z,' it's because we don't want people doing an explosion and a magic trick, and then 'Jazz hands - science!'

In the past, science centres and museums have been criticised on the grounds that science has been presented as 'easy and unproblematic' (Champagne, 1975;

Eshach, 2007); here we have evidence that festival organisers are aware of, and anxious to tackle, this issue.

While affective aims were key for teachers, educational aspects were also a concern for a sizeable minority, with $8 / 29$ respondents citing motivations such as 'To support/enhance curriculum taught to children in school,' or 'Learning about scientific

\section{${ }^{6}$ Names of WowFest organisers have been changed.}

${ }^{7}$ Names of WowFest organisers have been changed. 
concepts.' As mentioned, pupils cited broad aspects of learning as their understanding of motivation for the visit, with some specifying cognitive goals.

ii. Outcomes. An exploration of what school pupils stated they had learned on the day found that, in fact, many do experience a level of cognitive learning. We asked the question: 'Tell us a science fact that you learned at the festival.' Answers fell into four broad camps: cognitive, affective, descriptive and no answer.

We classified answers as descriptive if they described what the pupil had seen without any evidence of a deeper understanding; for example, 'The electric globe made your hair go up,' or 'I learnt that water can turn into ice with a trick.' Cognitive answers showed evidence of understanding, or that a specific fact had been learned; examples include: 'Clown fish change gender,' and 'The brain has more than one cell and also the cells learn about more than one thing.' Affective answers showed attitudinal shifts, eg 'That science is cool,' or 'You need maths for everything.' Finally a small number of answers were either irrelevant or incomprehensible, and were classified as null alongside those who did not answer at all.

In total, $45 \%$ of pupils gave responses that were classified as cognitive. In addition, $8 \%$ of pupils gave affective responses, which is notable considering that the question was phrased in such a way as to invite a factual response. Over half of respondents (34/64), therefore, gave clear evidence of learning.

\section{c. $\quad$ Science careers}

i. Expectations. A common theme across several of the festivals was a desire to raise awareness of the careers that science can offer. The WhizzFest organiser said: 'The big thing is connecting local school children with real scientists. So that we make science relevant and kids see it's happening all around them all the time, also that it's 
for them, people like them doing science and show that they can do it too.'

Similarly the LabFest organiser stated that they aim 'to raise awareness of science and the importance of STEM, and also to give the kids an idea about careers. We ask the person delivering to talk about careers... [It's] about choices, that's a key message, not just about the joy of science.'

The opportunity to challenge stereotypes about science and scientists was also mentioned. WowFest organiser Davina identified a primary aim as:

...seeing people in job roles that they perhaps hadn't considered to be science, or the kind of people that are in those roles.

Some teachers also saw careers information as a festival aim, with a few explicitly mentioning this aspect at each stage of the research:

[It] gives them the opportunity to meet scientists and see what jobs can be linked to science.

It opens up children's eyes to career avenues which they may not have been aware of or considered before.

The numbers of surveyed pupils, however, who identified careers information as a goal of the festival, was extremely small. One boy thought the best thing about the festival would be

Investigating the worker's jobs and how they was encouraged them to be a scientist. Also how they became a scientist and what skills u need to become one.

And one girl thought that the school was taking pupils to the festival To help inspire us to become scientists and engineers and helps us to understand science more. 
Such examples were, however, few and far between. A similar pattern was seen during the pre-event focus groups; despite the fact that a discussion had been held about pupils' views of science careers, only two pupils out of a total of 33 participants at this stage gave careers-based answers as to why the school wanted to take pupils to the event.

ii. Outcomes. With regards to learning about science careers, results from the WowFest pupil post-survey were mixed. Only 42\% (26/62)_of participants reported meeting a scientist, with a similar proportion (27/64) saying that they had found out about any new science jobs at the festival. In fact it was likely that most of the participants had met a scientist; one of the day's activities was a visit to a market-type area with stalls running hands-on activities. $\mathrm{M}_{2}$ and many of these stalls were manned by scientists from academia or local businesses. Teachers who were asked whether their pupils had had an opportunity to speak to a scientist almost all agreed.

In terms of the specifics of science careers, there is little evidence in the responses of children being aware of having met a scientist and being aware of their role; in fact only 9/64 respondents reported meeting individuals with roles such as 'marine biologist'. Meanwhile although $42 \%$ said they had found out about new science jobs at the festival, only $20 \%$ (13/64) actually named a job when asked 'If yes, what were they?' Again, an element of confusion was evident, with three pupils naming movie design/animation as a science job and several other respondents giving tangentially-relevant answers such as 'I discussed what jobs I would like to be when I am older, I want to be a doctor.' In total, only 9/64 respondents named a job that could involve working in science directly.

There was some suggestion, however, that the festival had gone some way to shifting attitudes towards science careers. Pupils were asked 'Did you want to be a 
scientist before you attended the festival?' and 'Do you want to be a scientist now?' Over a third (23/64 or $36 \%)$ said they were more positive about being a scientist after visiting the festival, while only 4/64 said they were less positive.

Asked whether attending the event had impacted pupils' understanding about what a scientist 'is' and does, several teachers said that the experience had broken down the stereotypical image of a scientist. 'I think the range of scientists they had the opportunity to see got rid of the idea that they are all in white coats and of a certain age,' said one, while another commented:

They can see scientists in different ways, see that you can use science in a lot of different ways. When you say the word scientists [they envisage] a white coat... but they have seen it's much wider than that now.

However teachers may have been optimistic in thinking that this message had got through to their charges; in fact there seemed to be a level of confusion among pupils about what constituted a scientist. For example, seven participants who reported not meeting a scientist then responded to the question 'If you answered yes, who were they?', with the answer 'staff'. There was also a methodological problem; the question was misinterpreted by a few pupils, who either gave the name of the scientist they had met or said they could not remember the name. As the aim was to find out the role of the person identified by the child as a scientist, this question needs to be reworked in any future research.

One teacher suggested that the fact that scientists at the event did not conform to the white coat stereotype could have caused confusion amongst the children:

'I think it's confused them a lot more. They were under the impression that a scientist wears a white lab coat and works in a sterile environment, and suddenly they are face with people with flamboyant taste in clothes who make exciting shows. It has really confused them, they expected them to be very stereotypical and

Formatted: Displayed quotation


have been thrown by the idea that you can use science, and call yourself a scientist, but still use pyrotechnics.'

\section{How effectively do the three stakeholder groups work together to optimise the learning experience on school trips to science festivals?}

a. Reduction of the 'novelty effect'

Too much novelty can affect learning ${ }^{8}$; Anderson and Lucas (D. Anderson \& Lucas, 1997), studying school trips to a science museum, found that 'students who underwent novelty reducing pre-orientation to the physical environment and had prior visitation experience learned more than their counterparts.' It is therefore helpful from a learning perspective if pupils embarking on a school trip have some idea as to what they are about to experience.

While most of the festivals stated that they gave teachers a certain amount of pre-festival information, little orientation information aimed at pupils was available. The WhizzFest organiser's response was typical: 'We pass it all on to the teacher and it is up to the teacher if they pass it on.' One exception was WowFest which produced short videos of experiment demonstrations to be shown to pupils before their visit. However these showed a lab interior rather than an overview of the festival.

Overall, only a minority of WowFest student participants experienced a preevent reduction in novelty, with $41 \%(26 / 63)$ agreeing that the festival was 'similar to what you were expecting'.

${ }^{8}$ Novelty levels which are too low can also affect learning; Anderson and Lucas (ibid.) note that 'Low levels of perceived novelty result in low levels of curiosity behaviour and low levels of on-task behaviour.' However science festivals are inherently novel environments due to their temporary nature. 
Whether the teacher had prepared the pupils for their forthcoming visit seems to be an important determinant of experience, as demonstrated by an analysis of our preand post-surveys among the pupils. We looked at those pupils who had completed both pre- and post-event surveys. Those who answered yes to the statement 'Has your teacher told you what will happen during your visit to WowFest?' in the pre-event survey were much more likely to say that the festival was similar to their expectations, with $61 \%(17 / 28)$ agreeing in the post-event survey. This was in contrast with $22 \%$ (7/32) of those whose teacher had not told them what would happen. Although numbers are small, this result is significant at $\mathrm{p}<0.01$ (Figure 1). In total, 57/124 of pupils said that their teachers had not told them what would happen during the festival.

The significance of the teacher's pre-event contribution was also seen in the post-survey question 'Did you know what your teacher expected you to do/learn at the festival?' (Figure 1). Pupils whose teachers had told them what would happen at the festival by and large knew what was expected of them, with 63\% (17/27) answering yes to this question. By contrast, those whose teachers had not told them what would happen were less likely to know what was expected of them, with only $42 \%(13 / 31)$ answering yes.

This effect is underlined by a focus group with a class of year 5 pupils from City Primary, a school in a deprived urban area, who said that their teacher had not given them any information about the festival other than it would be 'exciting'. Participant Foxy told us: 'They've told us absolutely nothing. They’ve left us hanging on everything.' When asked what they thought the festival was going to be like, some pupils were very vague, as in this exchange:

Facilitator: What do you guys think the festival's going to be like, then? Yes, Jeffy?

Jeffy: Awesome. 
Facilitator: In what way do you think it's going to be awesome?

Jeffy: I've just got it in my head. It's going to be awesome.

Other participants had a directly incorrect view of what the event would be like:

Facilitator: Yes, Poppy?

Poppy: I think people are going to dress up and act silly.

Facilitator: Right, okay. Yes, Ava?

Ava: People will be singing and dancing.

It may be particularly beneficial, from this perspective, to attend a science festival during more than one school year. This was highlighted by the pre-event focus group at Valley Primary, a very small school with a mixed year 5/6 class in which pupils often attend WowFest two years running. Year 6 pupils in the session talked at length about their experience at the festival the previous year; the students had, as a group, a very clear recollection of the trip, despite it being around 11 months previously. They spontaneously recalled individual activities that they had participated in, what the outcomes of various scientific investigations had been, the specific machines they saw and even the circumstances in which they ate their lunch. Pupils in the class who had been too young to attend the previous year heard from their older peers what they could expect. It is clear, therefore, that the class were primed for a significant reduction in novelty. This is illustrated by the words of participant Mango, who had attended the festival in year 5 and was looking forward to her year 6 visit:

\footnotetext{
I think it's kind of nice to be in a different place learning science, because it makes you excited and kind of intrigued what's going to happen, whereas in school you kind of know the routine, you know what's going to happen very, very well.
}

It is hard to say what proportion of pupils have the opportunity to visit a science festival with school more than once, as most festival organisers do not track individual 
pupils at this level, although all report that certain schools attend every year. However if schools tend to bring, for example, year 6 every year, this would mean that most pupils attend only once. Again, there was a range of experience; the LabFest organiser reported that the festival was aimed at one school year only, so no pupils would attend twice. By contrast, Experifest has quite a small number of schools in its catchment area, meaning that pupils have the opportunity to attend year-on-year.

\section{b. $\quad$ Agendas for the day's visit}

We have already discussed some areas in which a mismatch of visit motivations has the potential to negatively impact on learning, for example in gaining knowledge of careers, whilst in other areas - the desire to impart the excitement of science, for example there is a broad consensus of agendas between stakeholder groups.

However one further area which merits attention is an apparent deficit of explicit learning objectives on the part of teachers accompanying school trips. We asked teachers after the 2018 WowFest what learning objectives, if any, they had set their students for the visit. In total, around two-thirds of respondents either answered 'none' $(9 / 29)$ or gave no response (10/29). Of the remaining 10 respondents, two answered 'have fun' and three gave general answers such as 'ask questions, embrace learning'. Only four had set explicit learning tasks:

- Think about careers on an informal basis

- Write about four facts they learnt on the trip

- Look for ideas that we could try out in our after-school science club

- Identify a science concept that they can apply to everyday life

A strong pupil understanding of their teacher's motivations and expectations for a school trip is known to be beneficial for learning (DeWitt \& Storksdieck, 2008). In 
$\underline{\text { some settings, research suggests that pupil involvement in visit design can aid learning; }}$ $\underline{\text { for example, when designing their LIFTI model, Coll et al (Coll et al., 2015) found that }}$ "students became an essential part of field trip design... Teacher planners recorded a variety of problem solving activities proposed by students which was aligned with the objective of the visit." The students in question were aged 15 , so this approach does not directly translate to our current study of primary-age pupils, but the research reinforces the underlying concept that strong pupil understanding of the purpose of the visit is critical.

As previously mentioned, the majority of pupils in our study thought that the school's motivation for taking them to the festival was educational, ie learning-based, whether this be cognitive or affective. However few of the teachers that we surveyed appeared to have specific educational goals, potentially contributing to a lack of clarity for their pupils. Of the $67 / 124$ child participants whose teachers had told them something about what to expect during the trip, most gave rather vague answers to the question, 'What have they told you about it?', with typical responses being 'We can try different science activities,' or 'Fun things to see and do'. The teachers' rather vague aims for the visit may be reflected in these answers.

Similarly, after the festival half of respondents (30/61) said that they had not known what their teacher expected them to do and/or learn at the festival. Of the remainder, only 21/61 felt that they had been able to do what the teacher expected, and some of these gave answers such as 'Yes and she expected us to be quiet and to behave,' signifying expectations around behaviour rather than educational goals.

Whether or not teachers were clear about festivals' own educational goals is open to question, as information sent by organisers to teachers before the event tended to focus on operational matters such as transport and timetables. 
Interestingly, our pupil and teacher response data suggest a motivation for these groups that festival organisers may not currently be aware of - the opportunity for teachers to better understand their pupils' science interests. Town Hill pupil Amanda, made this suggestion:

I think Town Hill wants to take us because they want to see children enjoy it and see whether or not they like - want to know and see how they react to science and see how it actually is.

This was echoed by several teachers:

I'm going to let them choose what they learn about next from what they saw here. That way I know they're interested in it.

The ability for the children to access the show floor [where they can choose their own activity] so that as a teacher I can see the types of things they are interested in.

A couple of schools told researchers that they had set aside time after the festival to further explore topics that had particularly interested pupils on the day, or that they were planning related events such as science fairs.

The concept that the festival could be used by teachers to expand their knowledge of their class's science motivations was not a suggestion that was voiced during discussions with any festival organisers, although it was not explicitly raised by researchers as it arose organically from the responses of the other two groups. However there was no indication that organisers had considered the possibility of this benefit occurring.

\section{Discussion}

Our results show that there is a good match in learning aims between teachers and 
festival organisers, with the primary motivations being in the affective sector to provide excitement and inspiration via science. Although the pupil findings are somewhat vague on this point, with 'to learn about science' being the most common response to the question of why the school wanted them to attend the festival, there is some evidence that at least some respondents were thinking of learning in an affective sense in this instance.

Although not all pupils may have thought that they were at the festival in order to experience an attitudinal change towards science, there is significant evidence that this did, in fact, happen, with the vast majority of respondents reporting enjoying the experience and able to name an aspect that had particularly fired their interest.

Cognitive learning was a secondary aim for organisers and teachers, but there is evidence that such learning took place for just under half of school visitors, who were able to recall, and demonstrate some understanding of, a fact that they had learnt.

Overall, in terms of broad learning there seems to be a good alignment between the priorities of the three stakeholder groups, which led to successful learning outcomes. However there are four areas of mismatch where effort to better align the organisers' (and in some instances, teachers') aims with the pupils experience may produce better learning outcomes. We consider these in turn, and give recommendations for ways forward to improve the learning experience.

\section{Careers learning}

Although learning about careers was strongly indicated as an aim by festival organisers, as well as by some teachers, our pupil surveys gave little indication that this had, in fact happened, and only a very small number of students saw this as one of the aims of the festival. 
Pupils found it difficult to assess which of the people they encountered were 'scientists', did not seem to have grasped what their jobs were, and there was some indication that they were confused by the 'non-traditional' appearance and demeanour of the scientists at the event.

Our findings here broadly chime with those of Illingworth et al (Illingworth et al., 2015) who found that while the science event they studied was rated as interesting and enjoyable by the vast majority of students, fewer than half said their visit had made them more likely to pursue a career in science. The authors state that "...the science fair educated and enthused the school students about science... without educating and enthusing them about scientific careers". Teachers were also not motivated by the event $\underline{\text { to discuss science careers in the classroom. }}$

$\underline{\text { Illingworth et al have some useful and detailed recommendations as to how such }}$ events can address this issue, mainly aimed at secondary pupils which was the focus of their study. For primary pupils, they note that one teacher expected that the event would have "sown the seeds" of interest in scientific careers, which the author felt needed to be a more explicit aim. Our recommendations here are simple steps that could help to $\underline{\text { start the path towards scientific careers awareness among younger participants. }}$

In order to improve careers learning outcomes, both festival organisers and teachers could communicate to pupils in advance of the trip that part of the aim of the trip was for them to find out about new science jobs. This would then 'prime' participants to expect to encounter new ideas about careers in science.

In addition, organisers could make the professional roles of scientists clearer to the audience, rather than assuming that they will be easily interpreted as 'scientists', for example by asking those appearing to wear badges. Presenters could be asked to briefly discuss their professional roles. 
Recommendation 1: Festivals and teachers should tell pupils that one aim of the visit is for them to find out about new science jobs.

Recommendation 2: Festival organisers should ensure that pupils know that they are meeting a scientist and ask presenters to make their job roles clear to visitors.

\section{Novelty reduction}

Our results (Figure 1) demonstrate the striking effect that receiving some preparation from the teacher had on pupils attending WowFest, reducing novelty value and helping them to understand what the teacher expected from them. However only just over half of pupils (54\% or $67 / 124)$ reported that their teacher had told them what would happen on the trip. This, in turn, is maybe not surprising, as the festivals we studied produced little by way of information for pupils, with information sent to teachers focusing on the operational aspects of the visit. Teachers who had not themselves attended previously may have been unsure what to tell their class about the forthcoming visit.

To improve this situation, festival organisers could explicitly ask teachers to brief their pupils about what to expect from the festival. As many teachers may not be aware of the impact of novelty reduction on readiness to learn, a brief summary of the importance of preparation on learning could be used to encourage this.

In addition, festival organisers could take positive steps by providing materials to orient pupils before their visit, maybe in the form of a video, mocked-up visit diary, or checklist for teachers.

Recommendation 3: Festival organisers should explicitly ask teachers to give their pupils some simple information about the festival, explaining why novelty reduction is important from a learning perspective. 
Recommendation 4: Organisers should provide information to teachers that is intended to be disseminated to their pupils.

\section{Pupil understanding of teacher expectations/agenda}

Although the teachers surveyed in this study had motivations for the visit in line with those of festival organisers - mainly around learning in the affective sector - few had set or communicated any explicit learning goals to their students.

In the context of the literature around learning on school trips, this is unsurprising. As Đewitt and Storksdieck note:

...institutional constraints often hinder teachers' ability to maximize the learning 4

Formatted: New paragraph epportmities afforded by out of classroom experiences... In addition, research findings conflict as to the extent of teachers' awareness of the importance of recommended practices... Many teachers continue to use field trips simply as a 'day out'... Or focus on busy-work types of tasks and behavior management... Even when teachers seem aware of 'best' field trip practice, their own field trip implementation might still deviate from a 'best practice' script.' (DeWitt \& Storksdieck, 2008)

$\underline{\text { Remmen and Frøyland (Remmen \& Frøyland, 2015) note: }}$

Educational fieldwork in settings such as nature and museums can promote student motivation, knowledge and skills in and about science... To exploit this learning potential, teachers are recommended to prepare the students for the fieldwork, allow student-centered field activities, and follow-up on students' learning back in the classroom... However, studies have shown that teachers to not follow the recommendations; student preparation and follow-up work are often insufficiently addressed, and the pedagogy during the fieldwork is teacher-centered... Reasons for this include time constraints, curriculum-load, strict time tables, lack of financial resources, safety issues, school culture, low student motivation and low confidence in teaching outside the classroom... 
Meanwhile Morentin and Guisasola (Morentin \& Guisasola, 2015), who interviewed 158 teachers who were preparing a school visit to a science museum, have this blunt finding:

The results show that most teachers who visit this centre with their class group scarcely prepare for the visit, i.e. they do not have a clear idea of how to use the museum as an informal resource for learning about science.

The authors of the above study suggest that additions to initial teacher training, as well as CPD, should be used to address this issue. Given the pressures faced by teachers, however, it may behove science festival organisers to find ways to encourage them to set a learning agenda for the trip and communicate this in the classroom. Our research report focusing on structural issues (Canovan et al., 2019)_(YYYY (REDACTED), 2019)-recommends organisers consult teachers regarding festivalre design and content, and that they provide linked pre- and post-event educational materials to facilitate learning.

However, given that organisers and teachers share a primary motivation in the affective sector, we ask whether there is scope for festivals to support teachers in setting educational objectives in this area as well. A good starting point would be for festivals to make their own educational goals explicit.

Suggestions could be made for affective sector tasks that teachers could ask children to carry out during their visit, such as to choose the most exciting activity that they experience, find an example of science in 'real life' that they had not previously encountered, or look for examples of the breadth of science. Alternatively pupils could be asked to complete a post-event writing task with prompts about the most fun/inspiring/disgusting science that they saw.

Recommendation 5: Festivals should publicise their educational aims to schools. 
Recommendation 6: Organisers can support teachers in setting learning objectives by making suggestions for affective-sector activities.

\section{Teachers' knowledge of pupils' science interests/attitudes}

An interesting theme that emerged during the course of this study was the fact that some teachers used their science festival visit to discover which aspects of science sparked the greatest level of interest among their students, with some then planning follow-up activity based on the children's choice. Even when follow-up work was not planned, teachers found it beneficial for their teaching practice to discover more about the areas of science which were most motivational for their pupils. Although there was some evidence that pupils were aware of this aspect of their teacher's objectives for the visit, how widespread this awareness was is not clear.

In order to facilitate this, teachers could explicitly ask pupils which their favourite aspect of science seen on the trip was, and possibly timetable slots post-visit to explore these areas in more depth. Festivals could also facilitate this process by asking children what their favourite science area was through some simple means such as postit notes or a tick-box survey, and then sharing this information with schools.

Recommendation 7: Teachers could ask pupils what their favourite aspect of science was at the festival and then plan future classroom work in these areas.

Recommendation 8: Festival organisers could survey visiting pupils what their favourite aspect of the science on show was, and transmit this finding to schools.

\section{Conclusions}

The primary objectives for teachers and organisers of school trips to science festivals are well aligned, with affective learning - inspiration, excitement and improved 
attitudes to science - seen as the primary purpose, supported by a secondary goal of cognitive learning. Pupils saw the trips as broadly educational, with the aim being to 'learn about science', whether in the affective or cognitive sector. The broad alignment of the motivations of the three stakeholder groups led to significant learning taking place, with almost all pupils experiencing enjoyment and/or excitement about science, and around half reporting factual learning.

However in other areas, objectives for the three stakeholder groups were either less well aligned. Some motivations were not equally shared, while in other cases one group was unaware of an agenda shared by the other two parties. Perhaps the clearest example of this was in the case of learning about science careers; this was a strong aim of festival organisers, shared to some extent by teachers, but pupils in our study were unaware of this as a goal and little learning in this area took place. Similarly, some teachers were keen to use their visit to learn more about their pupils' science motivations, but festival organisers seemed unaware of this and therefore may be missing opportunities to facilitate such activity.

There were also areas in which opportunities were missed for the three groups to work together to optimise learning, particularly in the reduction of novelty for visiting pupils and in setting clear educational objectives that can then be transmitted to young people. This paper makes a series of eight recommendations that, if followed, have the potential to improve learning outcomes in a number of areas:

(1) Festivals and teachers should tell pupils that one aim of the visit is for them to find out about new science jobs.

(2) Festival organisers should ensure that pupils know that they are meeting a scientist and ask presenters to make their job roles clear to visitors. 
(3) Festival organisers should explicitly ask teachers to give their pupils some simple information about the festival, explaining why novelty reduction is important from a learning perspective.

(4) Organisers should provide information to teachers that is intended to be disseminated to their pupils.

(5) Festivals should publicise their educational aims to schools.

(6) Organisers can support teachers in setting learning objectives by making suggestions for affective-sector activities.

(7) Teachers could ask pupils what their favourite aspect of science was at the festival and then plan future classroom work in these areas.

(8) Festival organisers could survey visiting pupils what their favourite aspect of the science on show was, and transmit this finding to schools.

At this point it is appropriate to ask how researchers can do more to disseminate Formatted: New paragraph their findings and recommendations to festival organisers and teachers. As noted in this paper, although there is a large amount of academic literature giving recommendations on learning for school trips more broadly, there is little evidence of these being put into practice. While the literature on learning at science festivals specifically is still developing, it will be important to ensure that a similar phenomenon - that recommendations simply do not reach the target audience - does not occur. Fortunately, the science festival community, while growing, is still at a manageable size and has well-organised umbrella bodies, in the UK and US at least. By working with such organisations, researchers can help their findings to have a practical impact on young people's learning experiences at science festivals.

The science festival is a rapidly-growing phenomenon that is valued and enjoyed by its audiences. However in order to maximise educational impact and meet their own 
affective learning goals, those festivals who host school trips should take further steps to align themselves to the motivations of visitors, both teachers and pupils, and to communicate their own motivations to these target groups. By taking the actions suggested in this paper, the sector has the potential to improve learning outcomes and embed itself even more firmly as a valued facet of the out-of-school science education community. 


\section{Bibliography}

Anderson, D., \& Lucas, K. B. (1997). The Effectiveness of Orienting Students to the Physical Features of a Science Museum Prior to Visitation. Research in Science Education, 27(4), 485-495. Retrieved from https://link.springer.com/content/pdf/10.1007\%2FBF02461476.pdf

Anderson, D., Lucas, K. B., Ginns, I. S., \& Dierking, L. D. (2000). Development of knowledge about electricity and magnetism during a visit to a science museum and related post-visit activities. Science Education, 84(5), 658-679. https://doi.org/10.1002/1098-237X(200009)84:5<658::AID-SCE6>3.0.CO;2-A

Anderson, L. W., Krathwohl, D. R., Airasian, P. W., Cruikshank, K. A., Mayer, R. E., Pintrich, P. R., ... Wittrock, M. C. (2001). A Taxonomy for Learning, Teaching and Assessing : A Revision of Bloom's Taxonomy of Educational Objectives. Spring (Vol. 83). https://doi.org/10.1207/s15430421tip4104_2New York: Longman.

Archer, L., Dawson, E., Seakins, A., DeWitt, J., Godec, S., \& Whitby, C. (2016). “I'm Being a Man Here": Urban Boys' Performances of Masculinity and Engagement With Science During a Science Museum Visit. Journal of the Learning Sciences, 25(3), 438-485. https://doi.org/10.1080/10508406.2016.1187147.

Belin, C. (2018). Formal Learning in an Informal Setting: The Cognitive and Affective Impacts of Visiting a Science Center during a School Field Trip. Retrieved from http://seholarworks.urk.edu/etdhttp://scholarworks.uark.edu/etd/2701

Bultitude, K., McDonald, D., \& Custead, S. (2011). The Rise and Rise of Science Festivals: An international review of organised events to celebrate science. International Journal of Science Education, Part B, 1(2), 165-188. https://doi.org/10.1080/21548455.2011.588851

Canovan, C. (2019). "Going to these events truly opens your eyes". Perceptions of science and science careers following a family visit to a science festival. Journal of Science Communication, 18(2), 1-18. https://doi.org/10.22323/2.18020201

Canovan, C., Granger, L., \& Luck, C. (2019). Learning on school visits to science festivals (UCLan Widening Participation Reports 1). Preston: University of Central Lancashire. https://doi.org/10.13140/RG.2.2.23855.38561

Canovan, C., Granger, L., \& Luek, C. (2019). LEARNING ON SCHOOL VISITS TO SCIENCE FESTWVALS. https://dei.org/10.13140/RG.2.2.23855.38561 
Champagne, D. W. (1975). The Ontario Science Centre in Toronto: Some Impressions and Some Questions. Educational Technology, 15, 36-39.

https://doi.org/10.2307/44418321

Coll, S., Coll, R., \& Treagust, D. (2015). Making the most of out-of-school visits: How does the teacher prepare? Part I: Development of the Learner Integrated Field Trip Inventory (LIFTI). International Journal of Innovation in Science and Mathematics Education, 26(4), 1-19.

Dawson, E., Archer, L., Seakins, A., Godec, S., Dewitt, J., King, H., ... Nomikou, E. (2019). Gender and Education-Selfies at the science museum: exploring girls' identity performances in a science learning space. Gender and Education. https://doi.org/10.1080/09540253.2018.1557322

DeWitt, J., \& Storksdieck, M. (2008). A short review of school field trips: Key findings from the past and implications for the future. Visitor Studies, 11(2), 181-197. https://doi.org/10.1080/10645570802355562

Dieser, O., \& Bogner, F. X. (2015). Environmental Education Research Young people's cognitive achievement as fostered by hands-on-centred environmental education. Environmental Education Research, 22(7), 943957.https://doi.org/10.1080/13504622.2015.1054265

Eshach, H. (2007). Bridging in-school and out-of-school learning: Formal, non-formal, and informal education. Journal of Science Education and Technology, 16(2), 171-190. https://doi.org/10.1007/s10956-006-9027 1

Falk, J. H., \& Dierking, L. D. (1997). School Field Trips: Assessing Their Long-Term Impact. Curator: The Museum Journal, 40(3), 211-218. https://doi.org/10.1111/j.2151-6952.1997.tb01304.x

Finson, K. D., \& Enochs, L. G. (1987). Student attitudes toward science-technologysociety resulting from visitation to a science-technology museum. Journal of Research in Science Teaching, 24(7), 593-609. https://doi.org/10.1002/ter.3660240702

Fogg-Rogers, L., Bay, J., Burgess, H., \& Purdy, S. (2015). “Knowledge Is Power”: A Mixed-Methods Study Exploring Adult Audience Preferences for Engagement and Learning Formats Over 3 Years of a Health Science Festival. Science Communication, 37(4), 419-451. https://doi.org/10.1177/1075547015585006 
Griffin, J. (2004). Research on students and museums: Looking more closely at the students in school groups. Science Education, 88(SUPPL. 1), 59-70. https://doi.org/10.1002/sce.20018

Illingworth, S., Lewis, E., \& Percival, C. (2015). Does attending a large science event enthuse young people about science careers? Journal of Science Communication, 14(2), 1-16.https://doi.org/10.22323/2.14020206

Janiuk, R. M. (2013). USEFULNESS OF OUT-OF-SCHOOL LEARNING IN SCIENCE EDUCATIONUsefulness of out-of-school learning in science education. Journal of Baltic Science Education, 12(2) 128-129. Retrieved frem http://www.euscea.org/www.

Jensen, E., \& Buckley, N. (2014). Why people attend science festivals: Interests, motivations and self-reported benefits of public engagement with research. Public Understanding of Science, 23(5), 557-573. https://doi.org/10.1177/0963662512458624

Kisiel, J. (2005). Understanding elementary teacher motivations for science fieldtrips. Science Education, 89(6), 936-955. https://doi.org/10.1002/sce.20085

Knapp, D. (2000). Memorable Experiences of a Science Field Trip. School Science and Mathematics, 100(2), 65-72. https://doi.org/10.1111/j.1949 $8594.2000 . \mathrm{tb} 17238 . \mathrm{x}$

Morentin, M., \& Guisasola, J. (2015). PRIMARY AND SECONDARY TEACHERS' IDEAS ON SCHOOL VISITS TO SCIENCE CENTRES IN THE BASQUE COUNTRYrimary and secondary teachers' ideas on school visits to science centres in the Basque country. International Journal of Science and Mathematics Education, 13(1), 191-214. https://doi.org/10.1007/s10763-013$9481-1$

Mujtaba, T., Lawrence, M., Oliver, M., \& Reiss, M. J. (2018). Studies in Science Education-Learning and engagement through natural history museums. Studies in Science Education, 54(1), 41-

Formatted: Font: Italic, Not Highlight
Formatted: Not Highlight
67.https://doi.org/10.1080/03057267.2018.1442820

Partridge, N. (2003). Science out of the classroom. Journal of Biological Education, 37(2), 56-57. https://doi.org/10.1080/00219266.2003.9655851

Remmen, K. B., \& Frøyland, M. (2015). Supporting student learning processes during preparation, fieldwork and follow-up work: Examples from upper secondary 
school in Norway. Nordic Studies in Science Education, 11(1), 118-134. https://dei.org/10.5617/nordina.908

Whitesell, E. R. (2016). A day at the museum: The impact of field trips on middle school science achievement. Journal of Research in Science Teaching, 53(7), 1036-1054.https://doi.org/10.1002/tea.21322

Wiehe, B. (2014). When science makes us who we are: Known and speculative impacts of science festivals. Journal of Science Communication, 13(4), CO2.: 